\title{
REDUCTION IN FEV1\% IN WOMEN USING CHULLAFROM RURAL AREA OF PADMALE VILLAGE,SANGLI DISTRICT
}

\author{
P.M. Patil \\ Department of Zoology, Dr. Patangrao Kadam Mahavidyalaya, Sangli
}

\begin{abstract}
:
Biomass fuel such as wood, plant residues and cow dung especially used for cooking and heating purposes. The typical Indian household life revolves around the cooking area and Indian women spent much of the time there. For daily cooking Indian housewife spent on an average more than 6 hours in the kitchen for cooking food (morning and evening). During her lifetime she is exposed to biomass fuel for 30 to 40 yrs. The type of house, location of kitchen and type of fuel used play a significant role on women health. The smoke released due to incomplete combustion of unprocessed solid biomass fuel contains high volume and number of health damaging air borne pollutants such as(PM) respirable particulate matter PM10, CO, NO2, SO2, formaldehyde and other organic compounds. Prolong exposure to such air born pollutants have adverse effect on the respiratory system of women which causes COPD. COPD is the inflammation and swelling of the lining of the airways that leads to narrowing and obstruction of the airways. In rural areas, most common cause of COPD is air pollution. To study the COPD, in Padmale village of Sangli districts, 100 women were selected.50 women using chulla (subjects) and 50 women using LPG (control) were selected. All women were interviewed and information was collected on several factors associated with COPD including age, height, weight. Spirometry was performed in 100 subjects using chulla and LPG. COPD is diagnosed considering spirometry parameters such as forced expiratory volume/1 second (FEV1\%) and ratio of forced expiratory volume 1 second and forced vitalcapacity (FEV1/FVC\%). If $\mathrm{FEV} 1 \%<70 \%$ then there is COPD. In the present study we found out of 50 women who were exposed to biomass smoke 13 women(26\%) were having reduced FEV $1 \%$.
\end{abstract}

Key words: chronic obstructive pulmonary disease, spirometry (pulmonary function test), domestic smoke.

\section{INTRODUCTION:}

Half of the world population and $75 \%$ population of developing countries still depend upon biomass fuel as a primary source of domestic energy for cooking and heating. (Reddy, et al 1990; Desai, et al2004, Smith, et al.; 2004). Biomass fuel such as wood, plant residues and cow dunge specially used for cooking and heating purpose (Nigel Bruce, et al 1988) biomass accounts for more than $80 \%$ of domestic energy in India (Holdren et al ;2000).In India 90\% households use wood or animal dung as the primary cooking fuel (IIps). The most important factor in the life of average Indian housewife is the domestic cooking. The typical Indian household life revolves around the cooking area and Indian women spent much of the time there. For daily cooking Indian housewife spent on an average more than 6 hours in the kitchen for cooking food (morning and evening).During her lifetime she is exposed to biomass fuel for 30 to $40 \mathrm{yrs}$. The type of house, location of kitchen and type of fuel used play a significant role on women health.

The smoke released due to incomplete combustion of unprocessed solid biomass fuel contains high volume and number of health damaging air borne pollutants such as (PM) respirable particulate matter PM10, CO, NO2, SO2, formaldehyde and other organic compounds Prolong exposure to such airborn pollutants have adverse effect on the respiratory system of women which causes COPD.COPD is the inflammation and swelling of the lining of the airways that leads to narrowing and obstruction of the airways. In rural areas, most common cause of COPD is air pollution.

\section{MATERIAL AND METHODS:}

Total 100 women were participated in this study. The biomass fuel users group was represented 
by 50 women from Padmale village in Sangli district. Another group of LPG users was represented by 50 women from same village. All women were 25 years of age or older. Biomass fuel users were from low socio-economic status and exposed to biomass fuel smoke for more than 15 yrs and for minimum 6hrs. /day. All women were interviewed and information was collected about age, height, weight, type of house, type of Kitchen and literacy. Respiratory symptoms such ascough, phlegm, wheeze, and dyspnea were collected. Spirometry was performed in subjects $(n=50)$, and control $(n=50)$. Force expiratory volume/1 second (FEV1\%) and ratio of force expiratory volume/1second /force vital capacity were recorded. Women having $\mathrm{FEV} 1 \%<70 \%$ were considered as COPD

\section{Statistical analysis:}

$Z$ significance test was used. ' $Z$ ' value for control and subject was calculated, using formula based on null hypothesis to show significant difference between control and subject. To show consistency, coefficient of variation was calculated for control and subject.

$$
C a l|z|=\left[\frac{\overline{x 1}-\overline{x 2}}{\sqrt{\frac{\sigma 1^{2}}{n_{1}}+\frac{\sigma 2^{2}}{n_{2}}}}\right]
$$

\section{RESULT AND DISCUSSION:}

Table No.1 represents observations on Age, years of exposure and spirometry (in percentage) of control and Subject women in the village Padmale.

The mean values of Age and years of exposure of control women are 42.52 and 21.16. While mean values of Age and year of exposure of subject women are 43.92 and 21.90. The mean values of $\mathrm{FEV}_{1} \%, \mathrm{FVC} \%, \mathrm{FEV}_{1} / \mathrm{FVC} \%$, of control women are $100.77,90.46$ and 85.33 respectively, the mean values of $\mathrm{FEV}_{1} \%, \mathrm{FVC} \%, \mathrm{FEV}_{1} / \mathrm{FVC} \%$ of
Subject women are 68.26, 68.85 and 79.53 respectively. These values are shown at the base of each column in the Table No.1.

The calculated $Z$ value of Age and years of exposure and calculated $Z$ value of $\mathrm{FEV}_{1} \%$, $\mathrm{FVC} \%, \mathrm{FEV}_{1} / \mathrm{FVC} \%$ based on null hypothesis are at the last of each column in the Table No.1. The calculated $Z$ value of Age and years of exposure are 1.79 and 0.63 . The calculated $Z$ values of Age and years of exposure are less than 1.96 hence there is no significant difference in age and year of exposure of control and subject women. While calculated $Z$ values of $\mathrm{FEV}_{1} \%, \mathrm{FVC} \%$ and $\mathrm{FEV}_{1} / \mathrm{FVC} \%$ are $7.50,4.20$ and 5.16 respectively. The calculated $Z$ values of $\mathrm{FEV}_{1} \%, \mathrm{FVC} \%, \mathrm{FEV}_{1} / \mathrm{FVC} \%$ are greater than 1.96 hence there is significant difference in $\mathrm{FEV}_{1} \%, \quad \mathrm{FVC} \%, \mathrm{FEV}_{1} / \mathrm{FVC} \%$ of control and Subject women. The result is significant at $5 \%$ level of significance.

In this study we found that out of 50 women using chulla from rural area Padmale 13 women were having FEV1\% < 70. In Padmale 13 women were suffered from obstructive type of disorder. Duttet al. (1996) reported that the parameters $\mathrm{FVC} \%, \quad \mathrm{FEV}_{1} \%, \quad \mathrm{FEV}_{1} \%$ and PEFR were significantly lower in biofuel users compared with both kerosene and LPG users. Kirazet al. (2003) showed $\mathrm{FEV}_{1}$, values in rural women exposed to biomass fuels were found to be relatively low compared with those of urban women. Mangatet al. (2013) studied pulmonary function tests in rural women exposed to biomass fuel and reported that the lung function parameters $\mathrm{FEV}_{1}$ and $\mathrm{FEV}_{1} / \mathrm{FVC} \%$ were significantly lower in the study group exposed to biomass fuel than control. Our results are similar with the results Duttet al. (1996), Kirazet al. (2003) Mangatet al. (2013).

\section{REFERENCES:}

Desai, M.; Mehta S.; Smith, K. (2004): Indoor smoke from solid fuels assessingthe 
environmental burden of disease at national and local levels. Geneva, Switzerland, World Health organization.

Holdren, J.P. and Smith, K.R. (2000) : Energy, The environment, and health. InJ Goldemberg (Ed.)., The Word Energy Assessment: Energy and the Challengeof Sustainability (pp.61110)., New York: United National Development Programme.

Nigel Bruce, Lynnette Neufeld, Erick Boy, and chris west (1998): Indoor biofuel air pollution and respiratory health the role of confounding factors among women in highland Guatemala., International Journal of Epidemiology, Volume 27, 454-458.

IIPS - International Institute for Population Science. National family health survey (MCH and family planning); India 1992-93, International Institute for Population Science, Bombay 1995.

Reddy, A.; Williams, R; Johansson, T; editors, Energy after Rio, prospects andchallenges. United Nations Development Programme, New York: 1996.
Smith KR, Mehta S, Maeusezahl-Feuz M.: Indoor air pollution from household use of solid fuels comparative quantification of health risks. In:Ezzati MLA, Rodgers A, Murray CJL, editors Global and regional burden of disease attributable to selected major risk factors. Geneva, Switzerland: World Health Organization, 2004. pp. 1435-1493.

Dutta, D., Srinivasa, D.K., Rotti, S.B., Sahai, A., Konar, D. (1996): Effects of indoor air pollution on the respiratory system of women using different fuels for cooking in an urban slum of Pondicherry. Natl Med J India. 9:113117.

Kiraz, K., Kart, L., Demir, R., Oymak, S., Gulmez, I., Unalacak, M., Ozesmi, M. (2003): Chronic pulmonary disease in rural women exposed to biomass fumes. Clin Invest Med. 26:243-248.

Mangat, Empreet., Suchet T., Dashora L.S., Singh Surjit, Chouhan Swati. (2013): Pulmonary function tests in rural women exposed to biomass fuel. International journal of basic and applied physiology (IJBPA). 2(1):83-87.

Table No. - 1

Data of Spirometry (FEV $\%$, FVC\%, FEV 1 FVC\%) of Rural Women from PadmaleExposed to

Biomass smoke

\begin{tabular}{|c|c|c|c|c|c|c|c|c|c|c|}
\hline \multirow{2}{*}{$\begin{array}{l}\text { Sr. } \\
\text { No. }\end{array}$} & \multicolumn{5}{|c|}{ CONTROL } & \multicolumn{5}{|c|}{ SUBJECT } \\
\hline & Age & Years & $\operatorname{FEV}_{1} \%$ & FVC $\%$ & $\begin{array}{l}\text { FEV }_{1 /} \\
\text { FVC } \%^{2}\end{array}$ & Age & Years & $\operatorname{FEV}_{1} \%$ & FVC\% & $\begin{array}{l}\text { FEV }_{1 /} \\
\text { FVC } \%^{2}\end{array}$ \\
\hline 1 & 50 & 30 & 121.33 & 114.67 & 86.26 & 42 & 23 & 21.56 & 25.74 & 69.23 \\
\hline 2 & 46 & 28 & 92.79 & 91.43 & 86.16 & 36 & 18 & 87.58 & 86.26 & 88.47 \\
\hline 3 & 42 & 24 & 101.27 & 96.37 & 86.02 & 47 & 13 & 98.03 & 91.30 & 88.69 \\
\hline 4 & 48 & 31 & 101.27 & 96.37 & 86.02 & 42 & 24 & 53.37 & 36.36 & 80.56 \\
\hline 5 & 48 & 30 & 121.33 & 42.97 & 86.26 & 38 & 18 & 94.30 & 125.37 & 88.69 \\
\hline 6 & 48 & 10 & 98.03 & 91.30 & 88.69 & 40 & 17 & 50.18 & 84.65 & 83.04 \\
\hline 7 & 42 & 26 & 92.79 & 91.43 & 86.16 & 38 & 19 & 101.27 & 96.37 & 86.02 \\
\hline 8 & 49 & 33 & 105.18 & 102.62 & 86.38 & 49 & 25 & 92.79 & 91.43 & 86.16 \\
\hline 9 & 44 & 11 & 87.33 & 58.51 & 79.39 & 36 & 14 & 121.33 & 114.67 & 86.26 \\
\hline 10 & 52 & 32 & 77.00 & 61.07 & 77.19 & 48 & 30 & 53.37 & 36.36 & 80.56 \\
\hline 11 & 38 & 20 & 121.33 & 114.67 & 86.26 & 45 & 28 & 53.37 & 36.36 & 80.56 \\
\hline 12 & 40 & 21 & 92.79 & 91.43 & 86.16 & 48 & 30 & 54.46 & 67.47 & 69.05 \\
\hline 13 & 44 & 26 & 87.33 & 90.66 & 79.39 & 46 & 28 & 61.43 & 77.69 & 66.15 \\
\hline 14 & 40 & 13 & 101.27 & 96.37 & 86.02 & 40 & 13 & 54.46 & 67.47 & 69.05 \\
\hline 15 & 40 & 24 & 98.03 & 91.30 & 88.69 & 43 & 20 & 81.61 & 71.25 & 83.04 \\
\hline
\end{tabular}




\begin{tabular}{|c|c|c|c|c|c|c|c|c|c|c|}
\hline \multirow{2}{*}{$\begin{array}{l}\text { Sr. } \\
\text { No. }\end{array}$} & \multicolumn{5}{|c|}{ CONTROL } & \multicolumn{5}{|c|}{ SUBJECT } \\
\hline & Age & Years & FEV $_{1} \%$ & FVC\% & $\begin{array}{l}\text { FEV }_{1} / \\
\text { FVC } \%\end{array}$ & Age & Years & $\operatorname{FEV}_{1} \%$ & FVC\% & $\begin{array}{l}\text { FEV }_{1 /} \\
\text { FVC } \%^{2}\end{array}$ \\
\hline 16 & 36 & 20 & 87.58 & 86.26 & 88.47 & 41 & 22 & 33.08 & 36.36 & 80.56 \\
\hline 17 & 40 & 18 & 121.33 & 114.67 & 86.26 & 42 & 21 & 21.56 & 25.74 & 69.23 \\
\hline 18 & 38 & 19 & 121.33 & 114.67 & 86.26 & 41 & 20 & 92.79 & 91.43 & 86.16 \\
\hline 19 & 41 & 14 & 101.27 & 96.37 & 86.02 & 45 & 25 & 33.08 & 36.36 & 80.56 \\
\hline 20 & 43 & 22 & 87.33 & 90.66 & 79.39 & 44 & 14 & 121.33 & 114.67 & 86.26 \\
\hline 21 & 48 & 30 & 87.33 & 58.51 & 79.39 & 48 & 28 & 53.37 & 36.36 & 80.56 \\
\hline 22 & 47 & 29 & 121.33 & 114.67 & 86.26 & 42 & 23 & 61.43 & 77.69 & 66.15 \\
\hline 23 & 52 & 32 & 87.33 & 58.51 & 79.39 & 48 & 29 & 33.08 & 36.36 & 80.56 \\
\hline 24 & 42 & 20 & 98.03 & 91.30 & 88.69 & 48 & 27 & 54.46 & 67.47 & 69.05 \\
\hline 25 & 48 & 11 & 121.33 & 114.67 & 86.26 & 40 & 21 & 61.43 & 77.69 & 66.15 \\
\hline 26 & 42 & 25 & 83.04 & 61.07 & 83.04 & 48 & 13 & 53.37 & 36.36 & 80.56 \\
\hline 27 & 39 & 20 & 98.03 & 91.30 & 88.69 & 45 & 25 & 53.37 & 36.36 & 80.56 \\
\hline 28 & 36 & 12 & 83.04 & 61.07 & 83.04 & 42 & 21 & 53.37 & 36.36 & 80.56 \\
\hline 29 & 42 & 21 & 121.33 & 114.67 & 86.26 & 46 & 25 & 61.43 & 77.69 & 66.15 \\
\hline 30 & 46 & 28 & 101.27 & 96.37 & 86.02 & 43 & 23 & 54.46 & 67.47 & 69.05 \\
\hline 31 & 44 & 22 & 121.33 & 114.67 & 86.26 & 46 & 26 & 87.33 & 58.30 & 79.39 \\
\hline 32 & 38 & 18 & 121.33 & 114.67 & 86.26 & 48 & 28 & 61.43 & 77.69 & 66.15 \\
\hline 33 & 37 & 17 & 98.03 & 91.30 & 88.69 & 44 & 14 & 54.46 & 67.47 & 69.05 \\
\hline 34 & 40 & 10 & 98.03 & 91.30 & 88.69 & 48 & 27 & 87.58 & 86.26 & 88.47 \\
\hline 35 & 39 & 20 & 83.04 & 61.07 & 83.04 & 37 & 20 & 94.30 & 125.37 & 88.69 \\
\hline 36 & 42 & 21 & 105.18 & 102.62 & 86.38 & 45 & 25 & 53.37 & 36.36 & 80.56 \\
\hline 37 & 41 & 13 & 82.56 & 61.07 & 83.04 & 49 & 28 & 94.30 & 125.37 & 88.69 \\
\hline 38 & 38 & 19 & 92.79 & 91.43 & 86.16 & 43 & 14 & 21.56 & 25.74 & 69.23 \\
\hline 39 & 43 & 24 & 101.27 & 96.37 & 86.02 & 41 & 20 & 69.61 & 71.85 & 83.04 \\
\hline 40 & 38 & 19 & 87.58 & 75.26 & 88.47 & 44 & 23 & 53.37 & 36.36 & 80.56 \\
\hline 41 & 39 & 13 & 121.33 & 114.67 & 86.26 & 46 & 14 & 101.27 & 96.37 & 86.02 \\
\hline 42 & 42 & 21 & 121.33 & 114.67 & 86.26 & 48 & 24 & 96.02 & 91.43 & 86.16 \\
\hline 43 & 45 & 23 & 82.56 & 61.07 & 83.04 & 43 & 21 & 121.33 & 114.67 & 86.26 \\
\hline 44 & 46 & 26 & 82.56 & 61.07 & 83.04 & 45 & 13 & 52.01 & 61.07 & 83.04 \\
\hline 45 & 41 & 22 & 121.33 & 114.67 & 86.26 & 40 & 20 & 33.08 & 36.36 & 80.56 \\
\hline 46 & 37 & 18 & 101.27 & 96.37 & 86.02 & 39 & 20 & 96.02 & 91.43 & 86.16 \\
\hline 47 & 38 & 12 & 121.33 & 114.67 & 86.26 & 48 & 29 & 53.37 & 36.36 & 80.56 \\
\hline 48 & 45 & 26 & 87.58 & 86.26 & 88.47 & 48 & 28 & 121.33 & 114.67 & 86.26 \\
\hline 49 & 42 & 22 & 83.04 & 61.07 & 83.04 & 44 & 14 & 87.33 & 89.67 & 79.39 \\
\hline 50 & 40 & 12 & 105.18 & 102.62 & 86.38 & 49 & 30 & 53.37 & 36.36 & 80.56 \\
\hline Mean & 42.52 & 21.16 & 100.77 & 90.46 & 85.33 & 43.92 & 21.90 & 68.26 & 68.85 & 79.53 \\
\hline Var. & 17.13 & 40.53 & 210.43 & 416.24 & 7.96 & 13.39 & 28.61 & 729.47 & 906.47 & 55.28 \\
\hline Sqrt & 0.78 & 1.18 & 4.34 & 5.14 & 1.12 & & & & & \\
\hline$Z$ & 1.79 & 0.63 & 7.50 & 4.20 & 5.16 & & & & & \\
\hline
\end{tabular}

